
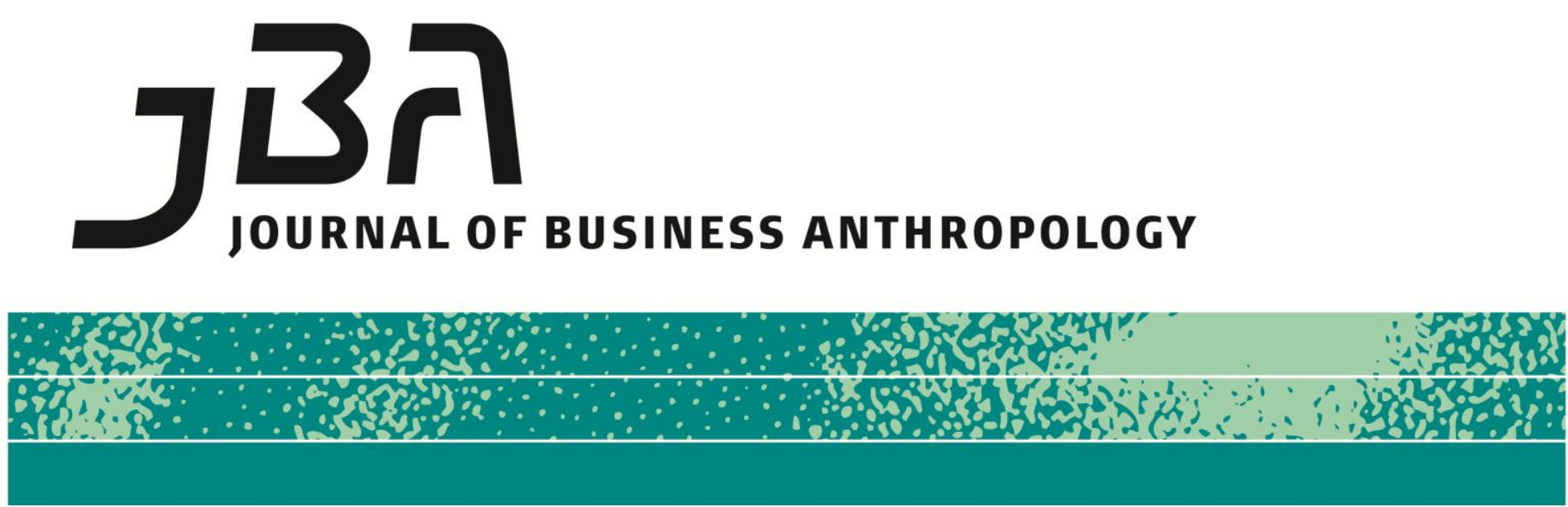

\title{
Elements of Reflexive Anthropology in Three Fieldwork Studies of the Workplace
}

Ghislaine Gallenga

\begin{abstract}
Focusing on the 'fictions' between the ethnographer and her informants, this article deals with the delicate chemistry of fieldwork through an account of three field studies. The first explores power struggles in a bank in Marseilles; the second looks at issues related to political and economic transition in Romania through as seen through the lens of a metalwork factory; the last analyses 'modernisation' in the public sector in Marseilles. These studies highlight some major questions raised in the field of reflexive anthropology, including the nature of the ethnographer/informant relationship, validation, gender issues, and the exploitation of the researcher. They reveal some of the difficulties surrounding the social construction of the ethnographer in the workplace and the negotiation of roles undergone whilst in the workplace. In these three cases the ethnologist was excluded from the field, forgotten about, and caught up in a conflict.
\end{abstract}

\section{Keywords}

Workplace anthropology, immersion, exploitation, reflexive anthropology.
Page 1 of 22

JBA 2(2): 187-208 Fall 2013

(C) The Author(s) 2013 ISSN 2245-4217

www.cbs.dk/jba 
'In a science in which the observer is of the same nature as his object of study, the observer himself is a part of his observation.' ${ }^{1}$

$$
\text { (Lévi-Strauss, 1950: xxvii). }
$$

The place of the researcher (Dalla Bernadina, 1989) in the preparation and the carrying out of ethnography has become, following postmodernist questioning of the role of the researcher, a much-discussed topic in the field of reflexive anthropology. However, most researchers place emphasis on the production of knowledge, rather than on the resulting textual analysis, provided that this reflexive approach works towards a better knowledge of the other while avoiding methodological narcissism (Leservoisier, 2005; Fainzang, 2002) or 'an excess of reflexivity', which occurs "when "I" takes up so much space in the writing that it replaces "they"' (Bouillon, Fresia and Tallio, 2005: 16). Postmodernist views include the idea that an anthropological account should reveal the 'fictions' (Geertz, 1998: 87) that emerge between the informant and the ethnographer by explaining interpersonal relations. In other words, this would amount to being more subjective in order to gain in objectivity. According to Olivier Leservoisier (2005), reflexive analysis is both a process allowing the objectification of research and a condition for knowledge production. As others are involved in the fieldwork process, the researcher is obliged to self-analyse because the collected data are dependent on her as much as they are on her informants. With postmodernist criticism of the status of written work and the scientific validity of fieldwork, reflexivity has become a major part of data analysis and presentation (Davies, 2008). Reflexive anthropology, however, has gradually been replaced, especially in the United States, by an anthropology of the self (Collins and Gallinat, 2010; Coffey, 1999), which shifts focus onto the necessity of integrating the researcher's personal experience and memories as ethnographic data.

This reflexive approach, therefore, appears to be inherent in the discipline itself and unconnected to the specificity of the field in which research is carried out. However, depending on fieldwork settings, the researcher's immersion will turn out to be either easy or awkward to some degree, and the roles s/he plays will vary considerably. I have often opted, during my research on the workplace, for the methodological approach of getting a job in the company to be studied - a choice which has advantages and disadvantages. ${ }^{2}$ All in all, the main benefit is that the researcher becomes integrated more easily (Erikson, 2002). When s/he has a position in the company, informants will not resort to stereotyped attitudes for fear of reprisal from management, such as acting like model employees, because the researcher shares the same work obligations.

\footnotetext{
${ }^{1}$ Every time a French citation is quoted in English, the translation is mine.

2 For a summary of these issues, see Le journal des anthropologues $(43-44,1991)$, and Gallenga (2007a).
} 
This method also enables the researcher to better contextualise informants' accounts. The main drawbacks are that the ethnographer will only be assigned a subordinate role (Krause-Jensen, 2013b: 49) and that she will be constantly caught between her position as an employee and her status as a researcher. More often than not, fieldwork in the workplace involves 'studying up' (Nader, 1974) and yet influential people in companies can often be difficult to observe.

But are there specificities to immersion in the workplace? Are the roles played by the ethnographer in the field less significant or different when research is carried out in companies? How are informants' representations of the ethnographer influenced by the fact that she is occupying a working position? What do the fictions at play between both sides reveal about immersion? Are these fictions heuristic, and to what extent do they contribute to a scientific validation of ethnography?

In an attempt to answer these questions, this article will deal with the delicate chemistry of fieldwork in the workplace, firstly through an account of three of my field studies focusing on the 'fictions' between the ethnographer and her informants. The first explores power struggles in a bank in Marseilles; the second looks at issues related to political and economic transition in Romania through an examination of a metalwork factory; the last analyses 'modernisation' in the public sector in Marseilles. Secondly, I will demonstrate how this research highlights some of the topics tackled in the field of reflexive anthropology - the nature of the ethnographer/informant relationship, data presentation, gender, and exploitation of the researcher. This research also accounts for the difficulties inherent in the ethnographer's social construction within a company, as well as the role negotiation faced by the ethnographer appointed to a working position. While each time I opted for the same methodological approach (getting a job in the company), there was a significant difference between these three cases when it came to fieldwork access. I was hired as an executive at the bank in Marseilles, without making reference to ethnological research, because of my degree in economics. In Romania, I was granted access to the field with no salary or stated mission from the company. Finally, I benefited from a three-year CIFRE $^{3}$ contract as a manager in a public transport company. These studies highlight some major questions raised in the field of reflexive anthropology, as mentioned above: the nature of the ethnographer/informant relationship, validation, gender issues and the exploitation of the researcher. They reveal some of the difficulties surrounding the social construction of the ethnographer in the workplace, and the negotiation of roles undergone whilst in the workplace. In these

3 'Convention industrielle de formation à la recherche dans les entreprises': a scheme supporting research in businesses, consisting of a grant allocated by the Ministry of Higher Education with the sponsorship of a company. The scholar is employed on a three-year contract as an executive in the company. 
three cases the ethnologist was either excluded from the field, or forgotten about, or caught up in a conflict.

\section{Three fieldwork settings in the workplace}

The anthropology of firms is a comparatively recently developed branch of anthropology in Europe. Initially limited to epistemological issues responding to social demand and questions of access to the field, it is now developing because of a number of applied anthropological research projects commissioned by institutions on interpersonal relationships in the workplace and aspects of globalisation.

In France, there is very little recent literature exploring the art of conducting anthropological studies of companies. In the paper by Nicolas Flamand and Monique Jeudy-Ballini (2002) which opened an issue of Terrain a decade ago, the authors point out that this branch of anthropology is seldom taught and largely underrated in Europe and is often confused with the anthropology of the working class or the anthropology of work. In the United States, on the other hand, the field of 'business anthropology' is widely taught, and hence more institutionalised (Ibid. p. 6), and is focused on being useful, outcomeorientated, and linked to the world of consultancy - issues which are still in their early developmental stages in Europe. However, Flamand and Jeudy-Ballini do not point to research in various other European countries - in particular, perhaps, Scandinavia (Sweden, Denmark, Norway) - where it is much more dynamic than in the rest of Europe (Gardner, 1977; Moeran, 2006; Garsten and Nyqvist, 2013a; KrauseJensen, 2013a), and where we can even find articles establishing the state of the art of this field (Garsten, 2011; Moore, 2011).

In North America, numerous articles have taken stock of ongoing developments in this field of anthropology, and not just in recent years (Burawoy, 1979; Baba, 1986;Bate, 1997). Books have been written on the subject, by whatever name, for a long time: A Companion to Organizational Anthropology (Caulkins and Jordan, 2013), Organizational Anthropology, Industrial Work and Life (Mollona et al., 2009), and Anthropology of Organizations (Wright, 1994) - none of which should be confused with 'organizational ethnography' as such, which also incorporates studies from the field of management focusing on ethnographic methods (Neylan, 2008; Ybema et al., 2009). Brian Moeran points to these separate fields with a pun in his book title: The Business of Ethnography (2006), while Christina Garsten and Anette Nyqvist (2013b: 242) note that:

Looking to the future, we have identified three themes salient to anthropological studies in and among complex organisations. They concern the very sites of our enquiry, how we engage with the field and the tools we use to conduct our 
studies.

In France, while we can find a handful of studies on companies, there is no manual or reference work in this field to date. A scene of power struggles and secrets, the workplace is quite an unusual fieldwork setting and a potential 'minefield' (Albera, 2001) with limited access. Brian Moeran (2006: 12) also comments on the fact that 'the study of business organizations itself is fraught with difficulties. Most companies are understandably reluctant to allow researchers free access to their premises, employees, or written records'. In addition, Jakob KrauseJensen (2013a: 5) notes that 'organizations are in some sense more clearly bounded than most other locations. It is necessary to get permission from high-standing employees to get access to the locality and to do research'.

In the 1980s-90s in France, one of the main issues tackled by researchers was how to gain access to a company. The debate about the relevance of getting a job in a company for research purposes has highlighted the methodological difficulties of this type of fieldwork. ${ }^{4} \mathrm{~A}$ methodological as well as an ethical issue, the decision to get a job increases the risk of the ethnographer becoming manipulated, as is often the case, but it has direct consequences in this particular context, especially as far as data production is concerned.

\section{Excluded from the field}

'An anthropologist has failed unless, when he says goodbye to the natives, there is on both sides the sorrow of parting.'

$$
\text { (E. E. Evans-Pritchard) }{ }^{5}
$$

I started working in the banking sector to support myself in the early 1990s. I approached this environment, which was to become the field for my research, as a manager and an authority figure. During job interviews I did not hide my interest in ethnological research. When I asked my superior for leave in order to participate in a conference, before being appointed to a permanent position, he answered bluntly:

"Ethnology is useless, especially if you work in a bank. We all have to make choices in life: either you wish to join the bank, in which case ethnology will not be of any use, or you wish to do ethnology, in which case you don't work in a bank. We expect our staff to be motivated and dedicated. If I find out you have taken just half a day off for ethnology, I'll simply fire you on the spot."

The status of ethnology within the bank had just been made abundantly clear! I was compelled to make a choice: give up anthropology or lose the

\footnotetext{
${ }^{4}$ For a summary of these issues, see Gallenga, 2007a.

${ }^{5}$ Quoted in Dalla Bernardina (1989: 13).
} 
opportunity I was offered. I decided to get round this impossible dilemma by pursuing my research in complicity with the bank manager ${ }^{6}$ (referred to below as deputy manager) and the rest of the staff, after telling them about the branch manager's blunt warning. I had been hired because of my degree in economics and I was now offered promotion. As it happened, the deputy manager advised me to avoid mentioning it in order to make my integration easier without provoking my colleagues' jealousy. She advised me to play the ethnology card: 'Tell them you are doing research on banking. No one cares about that, but don't say you have been hired through the graduate training scheme.'7 Ethnology thus became, at first, a way of defusing conflicts. I was facing a situation of paradoxical injunction. I could not comply with both the branch manager's command (you are an executive, not an ethnologist) and his deputy's recommendation (you are an ethnologist, not an executive).

I decided to continue my research on the bank itself without informing the branch manager. Any fieldwork relies on an implicit contract between the ethnologist and her informants (Abélès, 2002). In this particular case, the fact that I had chosen the bank as my research topic prompted my colleagues to see this secret as an implicit contract. In return for their silence, they deprived me of my legitimacy as an employee. My position as a team leader made me an authority figure, but gave me no power over the staff. The employees found themselves in a situation of double constraint and had to deal with this challenging ambiguity. For them, I should either go back to a subordinate role or give up ethnology - in which case they would have acknowledged me as a superior. Instead, they opted to denounce me via an anonymous letter sent to the bank's regional headquarters. I was immediately ordered to explain myself to the branch manager, while the Human Resources department decided to expel me from the graduate training scheme without notice. My superiors thus denied me access to key information which I could have obtained through my position in the scheme.

No one trusted me any longer. My superiors were concerned that I might take advantage of my knowledge. After its initial defusing effect, ethnology had become a weapon turned against me. Convinced that I would leave when my research was finished, employees no longer showed any solidarity towards me, even though I had been working towards improving their working conditions. At work, the atmosphere was very tense and everyone was trying to push me into some kind of professional misconduct in the hope that I would get fired. Actually, however, my greatest fear was that I would be forced to leave my

\footnotetext{
${ }^{6}$ On the bank's organisation chart, the bank manager is a deputy manager. Apart from the branch manager and his deputy, the branch that I worked in had six employees, all female with the same status, and a sales representative.

7 'Le vivier': a pool of graduates who are trained to become branch managers. Employees hired from the pool were destined to become executive or branch managers within two to five years after being recruited.
} 
fieldwork site before I had had time to collect enough data. So, in an attempt to postpone my now inevitable departure, I turned to the unions in order to defend myself. This allowed me to study the inner workings of trade unions throughout their meetings and during negotiations with management representatives. This close-up observation of union practices was made possible by my dual position as both ethnographer and employee. When I deemed that my fieldwork was over (which is always difficult for a researcher to assess), I finally resigned and received ten times more compensation than the statutory redundancy payment.

My active participation in the workplace may have biased some of my fieldwork results as I had partially contributed to the invention of the social environment I was studying. For example, I had talked one of my colleagues into refusing the branch manager's suggestion to work late hours or Saturdays. In a work context where relationships are strongly affected by the power struggles from which most conflicts arise, my ability to step back and to distinguish action from observation was inevitably challenged. After I left the bank, my former colleagues, concerned about my research being published, first asked me not to mention any informal practices involving breaking or ignoring the rules. Then, following changes within the branch management structure, they turned to me again, asking for feedback about the deputy manager's activities as they were trying to challenge her authority. In doing so, they acknowledged that ethnology was a weapon that I could have opted to use previously.

\title{
An ethnologist forgotten
}

\author{
O clipă de sinceritate \\ Te aduce la Securitate. ${ }^{8}$ \\ ('One moment of sincerity and you will face the Securitate.' \\ Romanian saying)
}

This exclusion of the ethnologist due to a lack of trust and a suspicion of spying happened again during my research in Romania, but this time with the ethnographer being fully integrated. After the fall of Nicolae Ceaușescu, in 1992, I worked in a large metalwork factory of 7,000 employees who produced industrial taps in Transylvania.

My study was carried out in Romanian without the help of an interpreter. The first stage of my stay allowed me to master the language while I was getting acquainted with the running of the factory. The company knew that the purpose of my presence was academic research, and had not specified any conditions for my stay with them except for the

\footnotetext{
${ }^{8}$ An allusion to the chorus of a popular Romanian song from before the revolution. La Securitate ('security' in Romanian), whose official name is Departamentul Securității Statului (Department of State Security), was Romania's secret police during Communism.
} 
impossibility of paying me a salary. In the 'job interview' described by Jakob Krause-Jensen (2013a: 6) in his book, we find the same characteristics: no salary, appointment to a role, six month fixed term, and first position in the Human Resources Department. During my fieldwork in the Marseilles City Transport Company (see below), the director also appointed me to the Department of Human Resources. It seems that the anthropologist is first and foremost defined by his alleged skills in social interaction. However, I was given total freedom for my work and offered two meals a day, in an area called the 'protocol' room where I was, more often than not, the only guest. From time to time, when prestigious (mostly foreign) guests were visiting the site, I was invited to dine with them and complied ceremoniously. Once again, an implicit contract was established. Management would use me as a symbol of openness in those times of political transition, in return for which I had no professional or academic obligation whatsoever. But such 'total freedom' was only relative and revealed a contradiction: in spite of his apparent open-mindedness and transparency, the chief executive tried to control my presence and my research methods.

My research, then, took shape according to the constraints of the field, as is often the case. On my first day, after a quick tour of the site, I was 'assigned' to an office of a new department called 'export quality', in which I was to work until the end of my stay. This department had a highly symbolic place in the company's organisation chart. Recently set up (after 1989), it aimed at presenting the company as modern and open to the outside world, in order to boost exports. Four French-speaking engineers worked there, including the wife of the department's director. As the only two women present, we developed a special bond resulting from her wish to make my integration into the company easier, mainly by learning Romanian. Our respective statuses - woman and director's wife; woman, French woman, ethnographer - modified our relationships with the opposite sex. Hence I benefited from a rapport based on both my gender and my nationality. The department manager asked me to make a list of all enquiries related to my research. He explained: 'We must be organised and I know all the departments: I will sort out enquiries between departments, then we will meet each manager accordingly to find answers.' His insistent manner led me to accept his request, so I patiently waited for answers while narrowing my research to administration services. Days and weeks went by and all managers said they were too busy to see me. Only the trade union spared me some time for a few interviews after a month. I was being put to the test of time, which reinforced the initial implicit contract.

Methodology in anthropology is often misunderstood, whether it is its long term aspect or the absence of questions. Malcolm Chapman (2001) makes this clear when he recounts - in the context of a study carried out in a company with a fellow economist - his colleague's response towards the methods of anthropology, especially the absence of 
a questionnaire. All my questions remaining unanswered. When I repeated my wish to work in the foundry, as was initially agreed with the company's management, I was told:

"You won't last long there. Work is too hard in the foundry and you will give up after one week... There is no point in you going to the foundry because the workers won't tell you anything or they will tell you lies. That's normal, that is how things are here."

This comment spells out one of the characteristics of this fieldwork setting: the difficulty of accessing important information or even freelyspoken, off-the-record comments. I wanted to join the foundry because, unlike in offices, work was organised in shifts. My time was organised into two blocks: the export quality department from $7 \mathrm{am}$ to $3 \mathrm{pm}$; and one afternoon or night shift in one of the foundries. During the last three months, I was given a shift as a worker, with the constraints of standards to comply with, in one of the factory's foundries, from $3-11 \mathrm{pm}$, or from $11 \mathrm{pm}$ to $7 \mathrm{am}$. In this foundry, sections were all male (engineers or workers), except for two. I made casts of internal parts for industrial taps within a section composed entirely of female workers. I also got a position in the section dedicated to the preparation of moulds to be painted - a section that consisted of both male and female workers. Occasionally, I took part in the foundry's extra shifts on Saturdays. By sharing the workers' daily lives (work, meals on the site, showers, activities and entertainment after work), I was able to gather information inside and outside the company.

The post-totalitarian background required that all information be carefully corroborated. In this case, the argument of secrecy was turned back on its authors: I got no more lies in the foundry than I had in the office. This reserved attitude towards a researcher - a stranger and, what's more, a foreigner - stemmed from the caution inherited from the previous regime: persistent fear and mistrust of the other, be s/he a stranger or a familiar face, potentially an informer working for the political police, the infamous Securitate. Although the Securitate was officially abolished on January 1st, 1990, the use of this heavily connoted word was by no means anachronistic. For all my informants, the Romanian Intelligence Service (S.R.I.) was but a new name for the old organization.

While the Director had accepted that I work shifts in the foundry, my arrival aroused many questions. My free access to information came up against more or less explicit obstacles during the course of my research. The arrival in the company of a foreign woman with ethnological purposes caused a stir in the factory. Therefore I had to find strategies in order to pursue my study, as I will later relate, although it was the subject of many different interpretations, as the final purpose of any ethnological study is often misunderstood. Everyone seemed to think 
that there were many potential uses in the gathering of facts concerning the company's intimate reality. Most importantly, the outcome of the study could become a potential threat (losing one's job), as every worker or engineer was aware. My presence in the field was subject to checks and integration strategies, hence creating the 'production of an ethnologist as an actor' (Althabe, 1990: 130). Within this complex interaction, I was essentially perceived as a spy, a fact which dramatically influenced my status as a fieldwork observer. In addition, my status as a French person and a woman in a mainly masculine environment was also the subject of specific perceptions and strategies.

\section{In the shadow of the Securitate ${ }^{9}$}

One particular feature of this fieldwork was that it was almost impossible to distinguish truth from falsehood and to avoid being caught up in a pattern in which everyone manipulated one another - out of personal interest or due to the Securitate's orders. The ethnologist was obliged to question every piece of information given and received, becaused suspicion and fear of the Securitate were still keenly felt. The figure of the foreigner as a potential spy not to be spoken to, and forty years of constant secrecy, were still present in the collective memory. I realised I was under surveillance, and this was confirmed by a few people who reported to me their conversations with the Securitate: my mail was opened, I was followed in the street, and I found out that my work hours were known to a few people. This surveillance had an impact on my living conditions. Rumours about my alleged activities circulated: for instance, that I carried in my handbag a powder compact fitted with a microphone recording everything all the time. My informants started to warn me frequently: 'You might get your handbag stolen in the street', or 'When you go to Bucharest, make sure you take all your work - tapes and documents - because you never know...'

These (more or less reliable) comments allowed me to assess what the Securitate thought of me. Initially considered as an industrial spy ${ }^{10}$ who was after information about Romanian technology, later I coincidentally came to be seen as a political spy using the factory as a cover (because I had entered the country at the same time and around the same area as the former King Mihai who was on a private visit). Finally, following my participation in two conferences on 'Human Relations in

\footnotetext{
${ }^{9}$ Although the Securitate was officially abolished in January 1990, the use of this heavily connoted word is by no means anachronistic. For all my informants, the Romanian Intelligence Service (S.R.I.) was just a new name for an institution whose structure and objectives were exactly the same as those of the former Securitate. Everybody still called this service by its old name. Even though this term had no legal meaning any longer, it testified to a sociological reality and will therefore be used throughout this article.

10 The accusation of spying, of course, is not specific to research in companies as every ethnologist faces it sooner or later in his/her fieldwork.
} 
Business' in Bucharest, I was suspected of being a business spy, supposedly employed by a French firm planning to buy out the company at a knock-down price. Even though these scenarios were not exactly the leads that the Securitate was following, it is worth noting that I was never considered as an ethnologist or even a researcher in social sciences.

My status within the company was also affected by allegations of espionage. This became clear in my relations with the unions, where I temporarily became persona non grata after union members had decided by a vote that I was a spy. My disgrace was ended after a chance encounter, in the protocol room, with the president of the federation to which the union was affiliated. Such an atmosphere of suspicion, inherited from communist times and associated with Romanians' usual wariness of strangers (as being potential surveillance officers), was a more or less implicit hindrance to my freedom of access to information. I was strictly denied access to all statistics and to details about the management. As a 'spy' I was nicknamed 'Mata Hari' or 'the pioneer' because my presence on site was a novelty. My colleagues started being sarcastic to me, which eventually created a bond. They would jokingly say things like 'your job title is “trainee turnătoare", isn't it?' I was not supposed to learn that 'turnător' meant both 'foundry worker' and 'informer'. ${ }^{11}$ No foundry workers had this word on their employee ID card, as their position was clearly mentioned (for example, 'electrician', 'section T1 worker', and so on), but as I was not an employee I had no such card.

\section{An ethnographer ready for marriage}

Living in similar conditions to the Romanians made my integration easier. The foundry was entirely male except for the two sections where I worked - one entirely female, where I made moulds for internal parts of industrial taps; the other mixed, where I prepared them for the painting stage. The arrival of an ethnologist always arouses curiosity and provokes various representations about her. The gender issue, for example, influences the practicalities of research. The fact that I was a French female complicated my integration. ${ }^{12}$ It gradually dawned on me that integration based on representations of gender and symbolic relationships could hinder the progress of my study, since factors linked to my femininity and to flirting came into play and reached a level where they impeded my research. For the actors, there was a double logic - my integration required my taking up a local lifestyle, whilst simultaneously I was expected to correspond to a certain stereotype. Romanians would generally agree that a French woman should have a certain style of clothing and education, as well as a high standard of living. Similarly, they

\footnotetext{
${ }^{11}$ From the verb a turna: to pour, to mould, to melt and, figuratively, to grass someone up.

12 For a detailed analysis see Gallenga, 2007b.
} 
characterized my gender in terms of my supposed fragility and libertarian values.

Faced with this image of a liberated woman, I constantly had to erect a certain barrier towards the men. On this issue, I agree with the views developed by Don Kulick and Margaret Wilson (1995) about how anthropologists' sexual identity in their own society affects the sexuality they are allowed to express in their fieldwork. In the offices, these expectations revolved around seduction and flirting, as dictated by stereotypes of my nationality. In the foundry, my integration did not depend on a stereotypical image of femininity: all discussions focused on the subject of sexuality in France and, in particular, of mine. Men and women questioned me from different standpoints. Men made advances towards me and women played the role of matchmaker. In such a coded situation, I was expected to find a husband in Romania. This interest shown in my personal life allowed the female workers to play the role of protectors, watching over me like sisters, and to inform me about certain marital customs. In order to become totally integrated, I was to marry into the community.

After several weeks working in the foundry, this situation became unbearable. I was making no progress in my research. At the start of every interview, male informants became flirtatious and women talked of finding my 'other half'. One of my strategies for avoiding these complications was to change my appearance, so I chose to 'neutralise' my gender in order to shift my role and informants' expectations, and get the research back on track. My strategy was to blur the boundaries of sexual categories. In externally adopting male characteristics, I tried to reverse the sex-orientated perceptions of my biological gender. I gave special attention to my clothing and appearance and decided to get rid of external signs of flirtation - lipstick, nail varnish, contact lenses, and so on - opting to tie back my hair, a very sexual attribute. Then, taking this change even further, I took on the attitudes of the other sex and wore the blue work overalls reserved for the men. This evolution of my clothes was accompanied by social practices such as drinking ţuică ${ }^{13}$ on a daily basis in the foundry with the workers, smoking coarse filter-less Carpaţi cigarettes and making male language practices such as swearing my own. ${ }^{14}$

All groups within the company defined me according to stereotypes of French women. My strategy was to blur the boundaries of sexual categories. As Odile Journet-Diallo (1999: 21-22) puts it, my status was:

vague in terms of the perception of physical characteristics hidden by appearance or clothes, but even more vague in terms of the symbolical categories which define a stranger not as

\footnotetext{
13 Home-made plum brandy, the alcohol content of which can be as much as $85^{\circ}$.

${ }^{14}$ For an analysis of swearwords in a work context, see Agnès Jeanjean, 1999.
} 
transsexual but primarily as sexless. This status makes it possible to play around the established boundaries of gender.

In externally adopting male characteristics, I tried to reverse the sexorientated perceptions of my biological gender. I was no longer a woman or a man, but a person without a well-defined gender. At the end of my stay, I was no longer a woman; neither was I a man; rather, I was just an ethnologist without a well-defined gender. It is through this process of 'neutralisation' of the ethnographer's own sexual attributes that I managed to get around elements that disrupted my research, in order to focus entirely on studying the company.

Subsequently, I returned to Romania for validation purposes and was well received by the management until they read my work. ${ }^{15}$ At that moment, it was made clear that 'the company did not wish to see me' and 'barred me from entering the factory' and, as if that was not enough, ordered me to 'never set foot in the town again'. As Françoise Zonabend (1994: 10) points out: 'because he often projects an image with which his informants have trouble identifying, the ethnologist becomes a sort of social con artist'. Validation becomes problematic - as was the case in Minot's research. Similarly, Malcolm Chapman (2001: 30-31) recounts the villagers' failure to understand Lawrence Wylie's book. In the context of a company, Philippe Erikson adds: 'But as soon as the contract ends, the doors are closed and it is paradoxically more difficult for an ethnologist to return "on visit" in a factory where he has worked than to a remote village in the bush where he used to live' (Erikson and Ghasarian, 2002: 119).

\section{Caught up in a conflict}

There is no sitting on the fence in speech: in sorcery, speech is war. Whoever speaks is involved and the ethnographer is no exception. There is no place for a neutral observer.

(Favret-Saada, 1977: 27)

Contrary to the above example, the integration of the ethnologist in a context of industrial action is never achieved and requires constant ongoing negotiation with the parties involved. The analysis of this strike is made in the context of a diachronic interpretation of the 'modernisation' processes of public service companies. I was working as a bus driver when a strike broke out at the Marseilles City Transport Company. At the root of the conflict was the problem of a double status rule specifying that newly-hired bus drivers would not benefit from the same salary conditions or the same work hours as their colleagues. This exceptionally long 33-day strike, supported by all trade unions and

15 My research touched on aspects of the economic, political and social transition of the country. I focused on the paradox of this transition: Romanian people were nostalgic about communism although they wanted capitalism. Through their understanding of privatisation and the role of trade unions, the management interpreted my study as a questioning of their educational role in this transition. 
followed by an exceptionally large number of strikers, led to the abandonment of this double status and profoundly marked the history of the company.

The strike that started in 1995, while I was conducting a study of the Marseilles City Transport Company (RTM) for my PhD (Gallenga, 2011), made such a reflexive moment possible. In the context of this research, I was working on the notion of public service and more precisely on the meaning of this notion for those who carry it out every day. I had decided to take up various roles within the company. ${ }^{16}$ While management had fancied for a short while that I could conduct my study incognito as a bus driver, for example, it soon had to yield to my ethical motives. All my informants knew the real reason behind my presence amongst them. I had been working in the Marseilles City Transport Company for over two years when the strike broke out. First I worked for a year in the RTM's administrative office. Then I got a position as a bus driver, which was my job when the strike started. When caught up in a conflict like this, how can the ethnologist complete her research?

In the history of strikes occurring regularly in RTM, the strike of December 1995 was particularly memorable. It was exceptionally long (33 days), supported by all trade unions, and had a very high proportion of strikers. This was a major event in the history of the company, as well as for my study. Paradoxically, my sitting on the fence and my wish to observe the conflict from within eventually led me to become a striker. The paradox of my position as a 'participant observer' was then revealed. I was caught up in a network of social expectations which pointed out that the actors - RTM management and trade unions alike - had failed to understand the participation of the ethnologist in the company in which she worked on two levels: first as an ethnographer, and second as an employee. Caught in a conflict, these actors did not believe that it was possible to keep some distance and perspective. Basically, all members of the company doubted the principle of professional secrecy that I guaranteed them. Through my knowledge of the running of the company at various levels of the hierarchy, I became a symbolic resource fiercely coveted by both management and trade unions: I was told to get off the fence. Every mention of my status as an ethnographer was interpreted as a blatant sign of betrayal, a diplomatic indication that I had chosen the opposite side. My methodological endeavours were turning against me.

There was obviously no understanding of a researcher's practice. However, this lack of understanding offered an opportunity for me to analyse the study situation - the backdrop to this interaction and the materialisation of the turmoil caused by the presence of an observer. During a strike, the power of collective challenges is so strong that it

16 I did all the required training courses, took the public service vehicle operator licence and worked as a bus driver, a station agent in the metro and a ticket inspector. 
leaves no room for understatement. Metaphorically speaking, a transformation occurred because of the strike: vague feelings caused by the presence of an ethnographer were suddenly expressed more clearly, mainly in an accusation of spying.

The strikers' main demand was the abolition of a 'new status' which penalised newly-hired bus drivers. It enabled the company to hire young drivers at a lower salary, with increased workload and reduced benefits package (social security, health insurance, choice of holiday periods). The aim of the strike was to reject this double status and go back to the previous situation - a common status for all employees appointed to the same role in the company.

Upon signing my contract, I was asked about my possible participation in a strike. As RTM had a long history of conflicts and strikes, it was very likely that one would occur during the next three years while I was there. The question was put to me bluntly and my answer was just as blunt. I told the CEO that I would rally to the majority. In other words, if the department or branch in which I was working voted in favour of the strike, I would join the strike - if not, I would carry on working. In any case, I would not take part in the vote, but the management (except the CEO) later disregarded this verbal agreement.

In the absence of pre-established formulae for fieldwork practices, the ethnographer must constantly adjust to her own injunctions and often make quick decisions which modify the study situation. The study of a strike raises the question of the study's feasibility. ${ }^{17}$ I chose to go on strike. The fact that I had manager status whilst being a bus driver triggered conflicting reactions among actors in the field. As I was the only executive apart from the bus depot manager, I could have positioned myself as a person in charge amongst the personnel. All of the staff, trade union representatives included, were confused by the presence of a newcomer who held a temporary contract, yet had executive status - as this was unknown within the company. The difficulty of identifying the newcomer became even more acute when 'she' declared that in addition to these peculiarities, 'she' was an ethnologist. These identifications were both revealed and blurred by the strike. The situation unfolded in three stages: firstly in my attitude at the outset of the strike; secondly in the resulting understanding of my position by the unions; and finally in management's ceasing to understand my position.

On the first day of the strike, my work hours were changed at the last minute. RTM management tried to break the strike by arranging for a manager to start work as the first buses were due to depart from the depot. According to management's representations, my executive status would prevail. I was supposed to toe the company line and not strike. Now, the ethnography of the conflict had already started and in order to

17 See Gallenga, 2005. 
see it through to completion, it was essential that I stay on the scene and follow the unions getting the depot ready for the strike. My working hours had been changed as part of a deliberate strategy which ignored my position as an ethnographer. Once again, my status as a researcher was pushed into the background as was the case during my previous studies. I encountered difficulties in integrating due to the ambivalence and peculiarities of my position: I was simultaneously a woman, a manager, a short-term employee, a striker, and an ethnologist to boot. This multiple identity was the cause of the exploitation of and misconceptions about the 'neutrality' I had to maintain.

The management attempted to exploit me mainly as an executive rather than as an academic. I was told that 'even though my heart leaned towards the strikers, however understandably, reason demanded that an executive hold rank', whilst management could have said: 'You are a researcher so stay out of all this'. My integration was difficult and I was once again considered as a spy and labelled with nicknames such as 'Mata Hari' or 'the mole'. However, having shown my 'neutrality' several times, I finally managed to get myself accepted by the union leaders, the unionists and the strikers. I was then able to follow the whole conflict - 33 days and nights - and attend all the negotiations at every level of decision-making.

At the beginning of the strike, I had wanted to follow the perspectives of both strikers and management. However, management dissuaded me from doing this, going so far as to threaten me. In other words, it appeared impossible to carry out an ethnography of all sides of the conflict. However, I ensured that I positioned myself within the ethnographer's atopy, as defined by Naepels (1998: 193), or in what I call a 'position of neutrality'. At the end of the strike, management tried to retain my wages for the days when I had been on strike. In its eyes, I was neither manager nor ethnologist, but simply a bus driver on strike. After this negotiation, there were still some months left on my contract. Management suggested that I stay at home during this period to write up my observations. This was only a pretext, as it had no interest in the interim report that I was due to hand in at the end of the contract.

Whilst the theme of espionage also crops up within the context of a strike, its nature and the terminology linked to it differ significantly. What we have here is a contrast between the representations of the 'spy' within and outside of the company. On the one hand, during the first two studies mentioned above, the 'spy' was viewed as an outsider about whom all levels of staff had a more or less common understanding. On the other hand, in the case of the strike, the 'spy' was carrying out internal espionage. In this case, both camps saw the ethnologist as belonging to the opposite side, thus indirectly legitimising her presence. For the unionists, this suspicion of espionage was eventually ended because of ongoing interaction with the ethnographer. Whereas the unions finally recognised her as an academic figure, this was not the case with 
management, who continued to ignore her status. The response of management towards the ethnographer's involvement in the conflict her way of being neutral - revealed a massive lack of understanding of the multiple statuses of the 'ethnologist as employee' in the field (that is a manager, a bus driver and an academic). Management gave more weight to the last two positions (bus driver and academic), combining them to create a new status, that of a radical intellectual in the tradition of the 'Établis' movement.

\section{Immersion and assignment}

The roles or assignments attributed to the ethnographer during her fieldwork study undeniably provide information about how informants objectify the relationship, but also about how 'the ethnographer as a person tries to take on some of these assignments' (Fogel and Rivoal, 2009: 5). This is particularly visible in the case of a strike. The stance taken by the ethnographer has allowed information and representations to be obtained, which informants were later able to 'process' by assigning either the role of 'striker' or that of 'consultant and strike specialist' to the ethnographer.

The question of assignment has a particular resonance when the ethnographer is a stranger in the society she observes. However, immersion 'at home' - as previously seen in the bank and the transport company - reveals similar but specific issues. At home, the categories used by informants are more likely to be part of the ethnographer's daily life. As Jakob Krause-Jensen (2013b: 44) points out, "'anthropology at home" is a tricky venture'. The epistemological difficulties of 'anthropology at home', usually examined through their relationship to distance and otherness, find a new resonance here. Roles were different in Romania, where the ethnographer's national representation was an additional factor. In the case of the ethnologist ready for marriage, I agree with Katia Boissevain when she wonders what happens when the role the ethnographer has been given does not suit him any longer, when 'the costume does not fit anymore? When he is bursting at the seams or when, on the contrary, the suit starts feeling too big for him, even though he has committed neither a faux pas nor a blunder?' (Boissevain, 2009: 2). Each ethnographer will attempt to answer these questions according to the various backgrounds and the possibilities at hand, in order to turn this bad role into a role that is better adjusted to his research purposes. The ethnographer will then try again to suggest another assignment to her informants.

The situation in the bank led to an unbearable position for the ethnographer. Isabelle Rivoal analyses the 'failure' of her ethnographical relationship during fieldwork in Lebanon 'in political terms, but in a specific context: the family' (Rivoal 2009: 11). She attempts to make sense out of her experience of moving in with a young married couple by 
analysing it 'in terms of domination and political division'. In the bank, the failure of the ethnographer's position may have derived from an immersion that was 'too successful': the ethnographer was so well integrated that the informants temporarily 'forgot' about her ethnographer status - only to remember it when required by political purposes.

This unbearable position is nevertheless heuristic. It has shed some light (in the instance of the excluded ethnographer) on the importance of power and authority struggles, as well as on the role of secrecy within a company. As Antoinette Molinié (2009: 1) notes: 'these assignments have an experimental value. They allow the ethnographer to grasp the fundamental structures of the society he is studying'. Contrary to Pierre Bourdieu's views (1980) that the ethnologist is able to objectify the practices he observes thanks to his position as an outsider, in the instance of the excluded ethnographer, it was being caught in the strategies of the actors that made it possible for me to objectify the observed practices.

\section{Conclusion}

In this article I have explored 'the dual dimension of the ethnographic paradigm 'I was there, I can talk about it' by demonstrating that 'being there' is often not enough to be able to talk about it and, more importantly, that the way of 'being there' always influences the way of 'talking about it" (Fogel and Rivoal, 2009: 3). I have thus 'considered the ethnographic relationship both as a specific time in fieldwork experience and as a way of producing data from the process of relations' (Ibid.). 'Being there' as a woman, and as a single woman, also influences the data collecting process. As Diane Bell and Pat Caplan have brilliantly demonstrated (1993), gender is never neutral in fieldwork; it is at least as significant as the chosen methodology.

These three research projects demonstrate that when an ethnologist enters the informants' world, he/she will be faced with a lack of understanding of his/her role. When analysed reflexively, they show that data production is closely linked to the choice of methodology. However, if occupying a working position allows a faster and less suspicious integration of the researcher when compared to being a mere observer, this method is nevertheless a best effort obligation rather than an obligation to produce a specific result. Issues of power and interpersonal relationships take the question of immersion through a working position beyond that of the researcher's integration. Having a role in the company places the informant in a double-bind situation which can explain why, after co-existing for a while, the tension caused by the researcher's duality leads to her eviction. It can be suggested that, even though occupying a job position makes the ethnographer's integration a lot easier, it can undermine her recognition as a researcher. When the 
ethnologist finds a position in the workplace, the actors focus on her status as an 'employee'. This situation blurs the informants' ideas of an ethnologist, even though her ethnologist status is still in the background and plays a role in interpersonal relations.

The world of business has been shown to be a field of study like any other in that the underlying aspects of research do not differ from those found elsewhere. In fact, it is not the field which creates these issues but the methodology (immersion, participant observation), which turns the ethnologist into a close stranger. The world of business however can bring a new heuristic perspective on these issues.

\section{References}

Abélès, Marc 2002. Le terrain et le sous-terrain. In C. Ghazarian (ed.), De l'ethnographie à l'anthropologie réflexive. Nouveaux terrains, nouvelles pratiques, nouveaux enjeux. Paris: Colin, 35-43.

Albera, Dionigi 2001. Terrains minés. Ethnologie Française XXXI (1) : 513.

Althabe, Gérard 1990. Ethnologie du contemporain et enquête de terrain. Terrain 14: 126-131.

Baba, Marietta 1986. Business and industrial anthropology: An overview. NAPA Bulletin 2. American Anthropological Association.

Bates, Paul S. 1997. Whatever happened to organizational anthropology? A review of the field of organizational ethnography and anthropological studies. Human Relations 50 (9): 1147-1175.

Bell, Diane, Caplan, Pat, and Wazir J. Karim (Eds.) 1993. Gendered fields: Women, men and ethnography. London and New York: Routledge.

Boissevain, Katia 2009. Décalages et rôles mal ajustés dans le travail ethnographique. Ateliers d'Anthropologie 33.

http://ateliers.revues.org/8204, Page consultée le 16 juin 2013.

Bouillon, Florence, Fresia, Marion, and Virginie Tallio 2005. Terrains sensibles. Expériences actuelles de l'anthropologie. Centre d'études africaines. Paris: EHESS.

Bourdieu, Pierre, 1980. Le sens pratique. Paris: Éditions de Minuit. Burawoy, Michael 1979. The anthropology of industrial work. Annual Review of Anthropology 8: 231-266.

Caulkins, Douglas D. and Ann T. Jordan (Eds.), 2013. A companion to organizational anthropology. Oxford: Wiley-Blackwell.

Chapman, Malcolm 2001. Social anthropology and business studies: some considerations of method. In D. Gellner and E. Hirsch (Eds.), Inside organizations: Anthropologists at work. Oxford: Berg Publishers, 19-33. 
Coffey, Amanda 1999. The ethnographic self: Fieldwork and the representation of identity. London: Sage.

Collins, Peter and Anselma Gallinat 2010. The ethnographic self as resource: Writing memory and experience into ethnography. New York and Oxford: Berghahn Books.

Dalla Bernardina, Sergio 1989. 'Équation personnelle’ et statut de l'observateur dans la tradition ethnologique. Sociologie du Sud-Est. Revue de sciences sociales 59-62: 7-26.

Davies, Charlotte Aull 2008. Reflexive ethnography: A guide to researching selves and others., Second Edition. London and New York: Routledge.

Erikson, Philippe and Christian Ghazarian 2002. Un terrain de 35 heures... Réflexions dialogiques sur les recherches d'anthropologie finalisée en entreprise. In C. Ghazarian (Ed.), De l'ethnographie à l'anthropologie réflexive. Nouveaux terrains, nouvelles pratiques, nouveaux enjeux. Paris: Armand Colin, 117-141.

Fainzang, Sylvie 2002. De l'autre côté du miroir. Réflexions sur l'ethnologie des anciens alcooliques. In C. Ghazarian (Ed.), De l'ethnographie à l'anthropologie réflexive. Nouveaux terrains, nouvelles pratiques, nouveaux enjeux. Paris: Colin, 63-71.

Favret-Saada, Jeanne 1977. Les mots, la mort, les sorts. Paris: Folio.

Flamand, Nicolas, and Monique Jeudy-Ballini 2002. Le charme discret des entreprises. L'ethnologie en milieu industriel. Terrain 39: 5-16.

Fogel, Frédérique and Isabelle Rivoal, 2009, Introduction, Ateliers d'anthropologie 33, La relation ethnographique, terrains et textes. http://ateliers.revues.org/8192, page consultée le 16 juin 2013.

Gallenga, Ghislaine 2005. Une ethnologue dans la grève. Ethnologie française XXXV (4): 723-732.

Gallenga, Ghislaine 2007b. Ethnologue à marier. La 'neutralisation' des attributs sexuels en entreprise. Ethnologies. 29 (1-2): 303-314.

Gallenga, Ghislaine 2007a. L’ « empathie inversée » : un heuristique de l'immersion en entreprise. In O. Leservoisier and L. Vidal (Eds.), L'anthropologie face à ses objets. Paris: Éditions des archives contemporaines, 153-160.

Gallenga, Ghislaine 2011. Le feu aux poudres. Une ethnologie de la modernisation du service public. Paris: Éditions du CTHS, coll. Le regard de l'ethnologue, $\mathrm{n}^{\circ} 25$.

Gardner, B. B. 1977. The anthropologist in business and industry. Anthropological Quarterly 50 (1): 171-173.

Garsten, Christina 2011. Recherche qualitative dans les organisations: éléments méthodologiques. Le Libellio d'AEGIS 7(2): 1-13. 
Garsten, Christina and Anette Nyquist (Eds.) 2013a. Organisational anthropology. Doing Ethnography in and among complex organisations. London: PlutoPress.

Garsten, Christina and Anette Nyquist 2013b. Momentum. Pushing ethnography ahead. In C. Garsten and A. Nyquist (Eds.), Organisational anthropology. Doing Ethnography in and among complex organisations. London: PlutoPress, 241-250.

Geertz, Clifford 1998. La description dense. Vers une théorie interprétative de la culture. Traduction d'André Mary. Enquêtes 6: 73-105. Jeanjean, Agnès 1999. Les égouts de Montpellier : mots crus et mots propres. Ethnologie française XXIX (4): 607-615.

Journal des Anthropologues 1991. Ethnologie de l'entreprise, 43-44. Journet-Diallo, Odile 1999. Catégories de genre et relation ethnographique chez les Joola du Sénégal. In Danielle Jonkers, Renée Carré et Marie-Claude Dupré (Eds.), Femmes plurielles. Les représentations des femmes, discours, normes et conduits. Paris: Maison des sciences de l'homme : 21-28.

Kulick, Don and Margaret Wilson 1995. Taboo. Sex, identity and erotic subjectivity in anthropological fieldwork. London and New York: Routledge.

Krause-Jensen, Jakob 2013a. Flexible firm. The design of culture at Bang \& Olufsen. New York and London: Berghahn.

Krause-Jensen, Jakob 2013b. Counter-espionage. Fieldwork among culture experts in Bang \& Olufsen. In C. Garsten and A. Nyquist (Eds.), Organisational anthropology. Doing ethnography in and among complex organisations. London: PlutoPress, 43-57.

Leservoisier, Olivier 2005. Terrains ethnographiques et hiérarchies sociales. Retour réflexif sur la situation d'enquête. Paris: Karthala.

Lévi-Strauss, Claude 1950. Introduction à l'œuvre de Marcel Mauss. In M. Mauss, Anthropologie et sociologie. Paris: P.U.F.

Lévi-Strauss, Claude 1958. Anthropologie structurale. Paris: Plon.

Moeran, Brian 2006. The Business of ethnography. Strategic exchanges, people and organizations. Oxford and New York: Berg.

Molinié, Antoinette 2009. Anthropologue prends garde! Trois assignations périlleuses sur trois terrains andins. Ateliers d'Anthropologie 33. http://ateliers.revues.org/8204, Page consultée le 16 juin 2013.

Mollana, M., Neve, de G., and J. Parry (Eds.) 2009. Industrial work and life. An anthropological reader. London: Berg.

Moore, Fiona 2011. Ambivalence, anthropology and business: a review of ethnographic research in international organisations. Social Anthropology/Anthropologie Sociale 19 (4): 506-519. 
Nader, Laura 1974. Up the anthropologist. Perspectives gained from studying up. In D. Hymes (Ed.), Reinventing anthropology. New York and Toronto: Vintage Books, 284-311.

Naepels, Michel 1998. Une étrange étrangeté. Remarques sur la situation ethnographique d'enquête. L'Homme 148: 185-200.

Neyland, Daniel 2008. Organizational Ethnography. Los Angeles, London, New Delhi, and Singapore: Sage Publications.

Rivoal, Isabelle 2009. Un huis clos ethnographique ou l'impossible enquête chez un ancien milicien libanais. Ateliers d'Anthropologie 33. http://ateliers.revues.org/8204, Page consultée le 16 juin 2013.

Wright, Susan 1994. Anthropology of organizations. London and New York: Routledge.

Ybema, Sierk, Yanow, Dvora, Wels, Harry, and Frans Kamsteeg (Eds.) 2009. Organizational ethnography. Stydying the complexities of everyday life. London: Sage Publications.

Zonabend, Françoise 1994. De l'objet et de sa restitution en Anthropologie. Gradhiva 16: 3-14.

Ghislaine Gallenga is a social anthropologist whose research has focused both on the anthropology of firms (including comparative research in the field of public service) and on reflexive anthropology (working on epistemological issues arising from ethnographic relations, empathy, and ethics). She is currently Associate Professor in Anthropology at Aix Marseille University (AMU), and researcher at the Institut d'ethnologie européenne méditerranéenne et comparative (IDEMEC - CNRS 7307), in Aix-en-Provence, France. She may be reached at gallenga@orange.fr 